\title{
Reduction of the Oxidative Stress Status Using Steviol Glycosides in a Fish Model (Cyprinus carpio)
}

\author{
Livier Mireya Sánchez-Aceves, ${ }^{1}$ Octavio Dublán-García, ${ }^{1}$ \\ Leticia-Xochitl López-Martínez, ${ }^{2}$ Karen Adriana Novoa-Luna, ${ }^{1}$ Hariz Islas-Flores, ${ }^{1}$ \\ Marcela Galar-Martínez, ${ }^{3}$ Sandra García-Medina, ${ }^{3}$ \\ María Dolores Hernández-Navarro, ${ }^{1}$ and Leobardo Manuel Gómez-Oliván ${ }^{1}$ \\ ${ }^{1}$ Laboratorio de Toxicología Ambiental, Facultad de Química, Universidad Autónoma del Estado de México, \\ Paseo Colón Intersección Paseo Tollocan s/n, Col. Residencial Colón, 50120 Toluca, MEX, Mexico \\ ${ }^{2}$ Centro de Investigación en Alimentación y Desarrollo, A. C. Unidad Culiacán, Carretera El Dorado Km 5.5, \\ Col. Campo El Diez, 80110 Culiacán, SIN, Mexico \\ ${ }^{3}$ Laboratorio de Toxicología Acuática, Departamento de Farmacia, Escuela Nacional de Ciencias Biológicas, \\ Instituto Politécnico Nacional, Unidad Profesional Adolfo López Mateos, Av. Wilfrido Massieu Esq. Cda. Miguel Stampa s/n, \\ Delegación Gustavo A. Madero, 07738 Ciudad de México, Mexico \\ Correspondence should be addressed to Leobardo Manuel Gómez-Oliván; lmgomezo@uaemex.mx
}

Received 15 December 2016; Revised 17 March 2017; Accepted 3 April 2017; Published 12 June 2017

Academic Editor: Vickram Ramkumar

Copyright (C) 2017 Livier Mireya Sánchez-Aceves et al. This is an open access article distributed under the Creative Commons Attribution License, which permits unrestricted use, distribution, and reproduction in any medium, provided the original work is properly cited.

\begin{abstract}
Steviol glycosides are sweetening compounds from the Stevia rebaudiana Bertoni plant. This product is considered safe for human consumption and was approved as a food additive by the Food and Drugs Administration (FDA) and European Food Safety Authority (EFSA). Its effects on the ecosystem have not been studied in depth; therefore, it is necessary to carry out ecotoxicological studies in organisms such as Cyprinus carpio. The present study aimed to evaluate the antioxidant activity by SGs on diverse tissues in C. carpio using oxidative stress (OS) biomarkers. To test the antioxidant activity, carps were exposed to four systems: (1) SGs free control, (2) $\mathrm{CCl}_{4} 0.5 \mathrm{~mL} / \mathrm{kg}$, (3) SGs $1 \mathrm{~g} / \mathrm{L}$, and (4) $\mathrm{CCl}_{4} 0.5 \mathrm{~mL} / \mathrm{kg}+\mathrm{SGs} 1 \mathrm{~g} / \mathrm{L}$ at $96 \mathrm{~h}$. The following biomarkers were analyzed: lipoperoxidation (LPX), hydroperoxide content (HPC), and protein carbonyl content (PCC), as well as antioxidant activity of superoxide dismutase (SOD) and catalase (CAT). It was found that both (3 and 4) systems' exposure decreases LPX, CHP, PCC, $\mathrm{SOD}$, and CAT with respect to the $\mathrm{CCl}_{4}$ system. The results of this study demonstrate that the concentrations of SGs used are not capable of generating oxidative stress and, on the contrary, would appear to induce an antioxidant effect.
\end{abstract}

\section{Introduction}

High-potency sweeteners are used to provide sweetness of taste without the calories associated with the consumption of sugar [1]. Growing consumption of sugar substitutes has gained importance due to their low caloric intake, potential health benefits, and reduced costs [2]. The most worldwide consumed sweeteners are aspartame (ASP), sucralose (SUC), acesulfame (ACS), saccharin (SAC), cyclamate (CYC), neotame (NEO), alitame (ALI), and neohesperidin dihydrochalcone (NHDC) [3].
Due to the growing incidence of both obesity and type 2 diabetes [4] and health-related concerns such as weight gain $[5,6]$, cancer risk [7], metabolic syndrome, hypertension, and pregnancy preterminal delivery risks [8-11] associated with the consumption of artificial high-potency sweeteners [12], much attention has been paid to low-calorie plantderived [13] sucrose substitutes. Nowadays, the food industry is increasingly interested in using natural sugars such as stevia instead of artificial sugars in order to offer a wider range of options for people who do not want or cannot eat sucrose [14]. 
Stevia rebaudiana Bertoni, an herb plant native to Paraguay and Brazil, produces sweet-tasting diterpene compounds as secondary metabolites in its leaves [15]. Stevia is the generic term used for all the compounds or substances derived from the plant Stevia rebaudiana Bertoni; nevertheless, the most accurate term for the group of intense sweetening compounds extracted from the plant is steviol glycosides (SGs) [16]. The main SGs found in stevia leaves are stevioside and rebaudioside. These compounds are 250-350 times sweeter than sugar and are widely used in food, beverages, and dietary noncaloric labeled products [17]. As SGs were recognized by the United States' Food and Drug Administration and the European Food Safety Authority as a GRAS (generally recognized as safe) product, it is expected that its global consumption rises to millions of metric tons in the coming years [17].

Globally, the stevia sweetener market is expected to grow from US\$ 347 million in 2014 to US\$ 565 million by 2020; in terms of volume consumption, stevia is expected to reach almost 8507 tons by the end of 2020 including suppliers such as Nestlé S.A., The Coca-Cola Company, and PepsiCo Inc. and producers such as Cargill Inc., Evolva Holding S.A., Pure Circle Ltd., Stevia Corp., Ingredion Inc., GLG Life Tech Corp., and Tate \& Lyle Plc. [18].

Several studies have shown that SGs regulate the content of sugar, radionuclides, and cholesterol in the blood [19]. They also exhibit anti-inflammatory and antitumor promoting properties [20] and insulinotropic, antihyperglycemic, antihypertensive [21-23], and antimicrobial activity [24].

On the other hand, oxidative damage to biological material is inflicted on all compounds of all major chemical classes: proteins, nucleic acids, carbohydrates, and lipids [25]. The inner balance between substances with prooxidant potential and the antioxidant defenses in biological systems [26] can be helpful to assess damage induced by the presence of pollutants in the environment. Carbon tetrachloride $\left(\mathrm{CCl}_{4}\right)$, a well-known hepatotoxic industrial solvent, has been found to provoke damage not only in the liver but also in other tissues such as blood, kidneys, brain, heart, testis, and lungs by generating free radicals [27-29]. Extensive evidence demonstrates that cytochrome $\mathrm{P} 450$ metabolic activation of $\mathrm{CCl}_{4}$ into free radicals $\left({ }^{*} \mathrm{CCl}_{4}\right.$ and $\left.{ }^{*} \mathrm{Cl}\right)$ induces lipid peroxidation and protein oxidation resulting in severe cell damage [30].

Oxidative stress, which is considered as one of the major mechanisms of action of toxicants, is among the most frequently used biomarkers since it is able to evaluate general damage to biomolecules such as lipids, proteins, and DNA [31]. Oxidative damage to lipids, proteins, and DNA and adverse effects on enzymatic antioxidant defense mechanisms in aerobic organisms have been used in recent years as biomarkers for monitoring environmental pollution [26]. The most important oxidative stress biomarkers used in toxicological studies of aquatic systems are LPX, hydroperoxide content, protein oxidation, and enzymatic antioxidant defenses [32].

Previous studies demonstrate that natural compounds with antioxidant properties may act against oxidative stress induced by $\mathrm{CCl}_{4}$ in fish models [33-35]. Therefore, the present study aimed to evaluate the antioxidant activity of
SGs on diverse tissues in the common carp Cyprinus carpio using oxidative stress (OS) biomarkers. OS will be induced using the $\mathrm{CCl}_{4}$ model.

1.1. Test Substances. Glycosides of steviol were used: stevioside (13-[(2-O- $\beta$-D-glucopyranosyl- $\beta$-D-glucopyranosyl)oxy]kaur-16-en-18-oic acid, $\beta$-D-glucopyranosyl ester; condensed formula: $\mathrm{C}_{38} \mathrm{H}_{60} \mathrm{O}_{18}$; CAS number: 57817-89-7; purity of this glycoside was $>99 \%)$ and rebaudioside-A (13-[(2-O$\beta$-D-glucopyranosyl-3-O- $\beta$-D-glucopyranosyl- $\beta$-D-glucopyranosyl)oxy]kaur-16-en-18-oic acid, $\beta$-D-glucopyranosyl ester; condensed formula: $\mathrm{C}_{44} \mathrm{H}_{70} \mathrm{O}_{23}$; CAS number: 5854316-1; purity of this glycoside was $>97 \%$ ). These products were provided by Sensient Flavors Mexico.

1.2. Fish Procurement and Maintenance. Cyprinus carpio species were obtained from a certified aquaculture facility located in Tiacaque, State of Mexico. The carps used for this experiment fit the following characteristics: $15.3 \pm 0.58 \mathrm{~cm}$ length and $30.01 \pm 4.5 \mathrm{~g}$ weight. Prior to toxicity studies, organisms were maintained for 30 days in tap water, at $20 \pm 2^{\circ} \mathrm{C}$, and exposed to natural light/dark photoperiods. Oxygen concentration was kept above $85 \%$, pH at 7.6-7.9, total alkalinity at $17.8 \pm 4.3 \mathrm{mg} / \mathrm{L}$, and total hardness at $18.5 \pm$ $0.4 \mathrm{mg} / \mathrm{L}$.

1.3. Oxidative Stress Determination. Test systems were prepared using water with the same characteristics and conditions described above in the Fish Procurement and Maintenance. The systems were static without renewal of the medium, and no food was provided to the specimens.

Previous studies were performed by determining the $\mathrm{CCl}_{4}$ concentration that induced OS used in this study $(0.15$, $0.3,0.44$, and $0.62 \mathrm{~mL} / \mathrm{kg} \mathrm{bw}$ ) according to Jia et al. [35]. The selected concentration of $\mathrm{CCl}_{4}$ was $0.5 \mathrm{~mL} / \mathrm{kg}$ bw.

In order to determine the concentrations of SGs used in this study, a previous experiment was performed using $\mathrm{CCl}_{4}$ $0.5 \mathrm{~mL} / \mathrm{kg}$ and different concentrations of SGs (70\% stevioside and $30 \%$ rebaudioside-A proportion): $0.1,0.2,0.3,0.4$, $0.5,0.6,0.7,0.8,0.9$, and $1 \mathrm{~g} / \mathrm{L}$. And the oxidative stress biomarkers analyzed in this work were evaluated. The only concentration that showed effects on the biomarkers used was $1 \mathrm{~g} / \mathrm{L}$ of SGs, so this was the one selected.

To test the antioxidant activity of SGs, four systems were tested: (1) SGs free control, (2) $\mathrm{CCl}_{4} 0.5 \mathrm{~mL} / \mathrm{kg}$, (3) SGs $1 \mathrm{~g} / \mathrm{L}$, and (4) $\mathrm{CCl}_{4} 0.5 \mathrm{~mL} / \mathrm{kg}+\mathrm{SGs} 1 \mathrm{~g} / \mathrm{L}$. Each system used 6 carps and the assays were performed in triplicate (72 fish were used in the oxidative stress evaluation). In the systems containing $\mathrm{CCl}_{4}$, the fish were given a caudal vein injection of $\mathrm{CCl}_{4}$ (30\% in olive oil) at a dose of $0.5 \mathrm{~mL} / \mathrm{kg}$ body weight. The target concentrations used in this experiment were based on previous experiments $(0.29,0.58,0.87$, and $1.0 \mathrm{~g} / \mathrm{L}$ SGs). These concentrations were determined by experimental design central composite (STATGRAPHICS Centurion XVII version). The concentration of SGs selected was $1.0 \mathrm{~g} / \mathrm{L}$. At the end of the exposure period $(96 \mathrm{~h})$, blood was removed by puncture of the caudal vessel, and liver, muscle, gills, and 
brain were removed from each specimen. Organs and tissues were placed in phosphate buffer solution (PBS) $(0.138 \mathrm{M}$ $\mathrm{NaCl}, 0.0027 \mathrm{KCl}$ (Vetec, Sigma-Aldrich, Mexico)) at pH 7.4 and then centrifuged at $12,500 \times \mathrm{g}$ and $-4^{\circ} \mathrm{C}$ for $15 \mathrm{~min}$. The following biomarkers were then evaluated: hydroperoxide content (HPC), lipoperoxidation (LPX), and protein carbonyl content (PCC), as well as the activity of the antioxidant enzymes superoxide dismutase (SOD) and catalase (CAT). All bioassays were performed on the supernatant.

1.4. Determination of HPC. HPC was determined by Jiang et al.s [36] method. $100 \mu \mathrm{L}$ of the supernatant (previously deproteinized with $10 \%$ trichloroacetic acid; Sigma-Aldrich, St. Louis) was mixed with $900 \mu \mathrm{L}$ of the reaction mixture

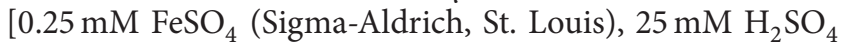
(Sigma-Aldrich, St. Louis), $0.1 \mathrm{mM}$ xylenol orange (SigmaAldrich, St. Louis), and $4 \mathrm{mM}$ butyl hydroxytoluene (SigmaAldrich, St. Louis) in 90\% (v/v) methanol (Sigma-Aldrich, St. Louis)]. The mixture was incubated at room temperature for $60 \mathrm{~min}$ and absorbance was read at $560 \mathrm{~nm}$ against a blank containing only reaction mixture. Results were interpolated on a type curve and expressed as nM CHP (cumene hydroperoxide; Sigma-Aldrich, St. Louis)/mg protein.

1.5. Determination of LPX. LPX was determined using thiobarbituric acid-reactive substances, as described by Buege and Aust's [37] method. To $100 \mu \mathrm{L}$ of supernatant, Tris- $\mathrm{HCl}$ buffer solution ( $\mathrm{pH}$ 7.4) (Sigma-Aldrich, St. Louis) was added until a $1 \mathrm{~mL}$ volume was attained. Samples were incubated at $37^{\circ} \mathrm{C}$ for $30 \mathrm{~min} ; 2 \mathrm{~mL}$ of TBA-TCA reagent [ $0.375 \%$ thiobarbituric acid (Fluka-Sigma-Aldrich, Toluca, Mexico) in 15\% trichloroacetic acid (Sigma-Aldrich, St. Louis)] was added and samples were shaken. They were then heated up to boiling for $45 \mathrm{~min}$ and then allowed to cool down, and the precipitate was removed by centrifugation at $3,000 \times \mathrm{g}$ for $10 \mathrm{~min}$. Absorbance was read at $535 \mathrm{~nm}$ against a reaction blank. Malondialdehyde (MDA) content was calculated using the molar extinction coefficient (MEC) of it $\left(1.56 \times 10^{5} \mathrm{M} / \mathrm{cm}\right)$. Results were expressed as $\mathrm{mM}$ MDA/mg protein.

1.6. Determination of PCC. The method of Levine et al. [38] modified by Parvez and Raisuddin [39] and Burcham [40] was used for determining PCC. Soluble proteins were obtained by centrifugation of samples at $10,500 \times \mathrm{g}$ for $30 \mathrm{~min}$. A test tube was filled with $100 \mu \mathrm{L}$ of supernatant and $150 \mu \mathrm{L}$ of $10 \mathrm{mM}$ DNPH in $2 \mathrm{M} \mathrm{HCl}$; the tube was incubated at room temperature for $1 \mathrm{~h}$ in the darkness. After the incubation time, $500 \mu \mathrm{L}$ of $20 \%$ trichloroacetic acid was added, and the solution was allowed to rest for $15 \mathrm{~min}$ at $4^{\circ} \mathrm{C}$. The sample was centrifuged for $5 \mathrm{~min}$ at $11,000 \times \mathrm{g}$. Using the solution of $1: 1$ ethanol: ethyl acetate, the bud was washed three times and then dissolved in $1 \mathrm{~mL}$ of $6 \mathrm{M}$ guanidine solution ( $\mathrm{pH} 2.3$ ) and incubated for $30 \mathrm{~min}$ at $37^{\circ} \mathrm{C}$. Absorbance was read at $366 \mathrm{~nm}$. Results were expressed as $\mathrm{nM}$ reactive carbonyls formed $(\mathrm{C}=\mathrm{O}) / \mathrm{mg}$ protein, using the MEC of $21,000 \mathrm{M} / \mathrm{cm}$ [41].

1.7. SOD Activity Determination. According to the Misra and Fridovich's method [42], the activity of SOD was determined.
In a $1 \mathrm{~cm}$ cuvette, $40 \mu \mathrm{L}$ of the supernatant, $200 \mu \mathrm{L}$ of adrenaline $(30 \mathrm{mM})$, and $260 \mu \mathrm{L}$ of carbonate buffer solution $(50 \mathrm{mM}$ sodium carbonate and $0.1 \mathrm{mM}$ EDTA) ( $\mathrm{pH} 10.2)$ were added. Absorbance was read at $480 \mathrm{~nm}$ after $30 \mathrm{~s}$ and $5 \mathrm{~min}$. SOD activity was determined using the MEC of SOD $(21 \mathrm{M} / \mathrm{cm})$. Results were expressed as IU SOD/mg protein [41].

1.8. CAT Activity Determination. According to Radi et al.s [43] method, the activity of CAT was determined. A test tube was filled with $20 \mathrm{~mL}$ of the supernatant, followed later by addition of $1 \mathrm{~mL}$ of isolation buffer solution [0.3 M saccharose (Vetec-Sigma-Aldrich, St. Louis), $1 \mathrm{~mL}$ EDTA (SigmaAldrich, St. Louis), 5 mM HEPES (Sigma-Aldrich, St. Louis), and $5 \mathrm{mM} \mathrm{KH}_{2} \mathrm{PO}_{4}$ (Vetec-Sigma-Aldrich, St. Louis)], plus $0.2 \mathrm{~mL}$ of a hydrogen peroxide solution $(20 \mathrm{mM}$, VetecSigma-Aldrich, St. Louis). Absorbance was read at $240 \mathrm{~nm}$ after 0 and $60 \mathrm{~s}$. The absorbance value was used in the formula CAT concentration $=\left(A_{0}-A_{60}\right) / \mathrm{MEC}$, where the MEC of $\mathrm{H}_{2} \mathrm{O}_{2}$ is $0.043 \mathrm{mM} / \mathrm{cm}$, and the results were expressed as $\mu \mathrm{M}$ $\mathrm{H}_{2} \mathrm{O}_{2} / \mathrm{mg}$ protein [41].

1.9. Determination of Total Protein. $25 \mu \mathrm{L}$ of the supernatant was mixed with $75 \mu \mathrm{L}$ of deionized water and $2.5 \mathrm{~mL}$ of Bradford's reagent. The mix was shaken in a vortex for $1 \mathrm{~min}$ and then stored without light for $5 \mathrm{~min}$. Absorbance was read at $595 \mathrm{~nm}$ and the results were interpolated on a bovine albumin curve. Total protein analysis was determined by the Bradford [44] method.

1.10. Statistical Analysis. Results of the oxidative stress biomarkers were statistically evaluated by one-way analysis of variance (ANOVA), followed by Bonferroni's multiple comparisons test, with $P$ set at $<0.05$. Statistical determinations were performed with SPSS v10 software (SPSS, Chicago, IL, USA).

\section{Results}

2.1. Hydroperoxide Content (HPC). The amount of cumene hydroperoxide (CHP) equivalents induced by different systems is shown in Figure 1. Significant increases with respect to the control $(P<0.05)$ were observed in the treatment with $\mathrm{CCl}_{4}$ in blood, gill, and brain in 892.1, 457.1, and 250.4\%, respectively. In the SGs system, significant decreases were observed with respect to the control $(P<0.05)$ in blood (91.3\%), liver (82.9\%), and gill (94.4\%). No significant differences were observed in the treatment with $\mathrm{SGs}+\mathrm{CCl}_{4}$ in any tissue. Significant decreases $(P<0.05)$ with respect to the $\mathrm{CCl}_{4}$ were found in all tissues in the SGs system. The SGs + $\mathrm{CCl}_{4}$ system showed significant decreases $(P<0.05)$ with respect to the $\mathrm{CCl}_{4}$ system in blood, liver, muscle, gill, and brain in $96.0,80.9,83.7,76.2$, and $81.7 \%$, respectively.

2.2. Lipoperoxidation (LPX). LPX results are shown in Figure 2. Significant increases with respect to the control group $(P<0.05)$ were observed in the system with $\mathrm{CCl}_{4}$ in blood, liver, gill, and brain. These increases were 92.6, 434.9, 99.9, and $171.5 \%$, respectively. Significant decreases with respect to 


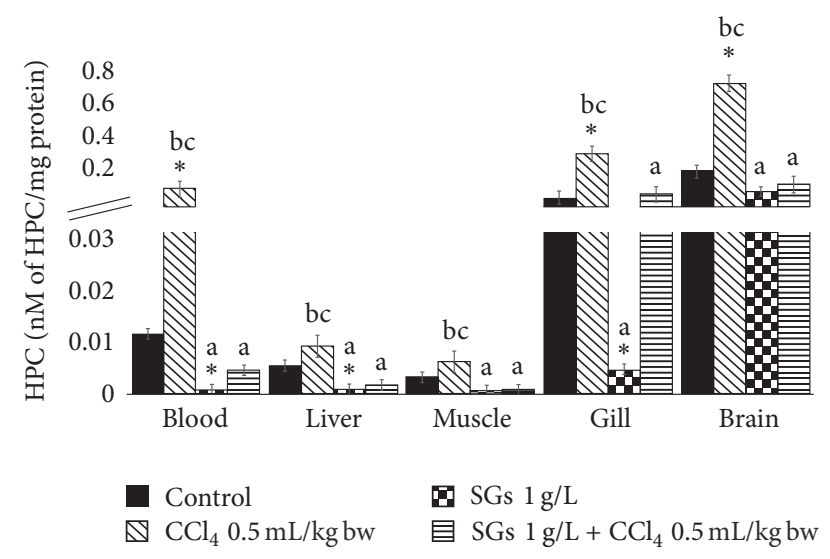

FIgURE 1: HPC in blood, liver, muscle, gill, and brain of C. carpio exposed at $96 \mathrm{~h}$ in different systems. Values are the mean of three replicates \pm SEM. $N=72$ carps. CHP: cumene hydroperoxide. Significantly different $(P<0.05)$ from $*=$ control, $\mathrm{a}=\mathrm{CCl}_{4}, \mathrm{~b}=\mathrm{SGs}$, and $\mathrm{c}=\mathrm{SGs}+\mathrm{CCl}_{4}$. ANOVA and Bonferroni's test.

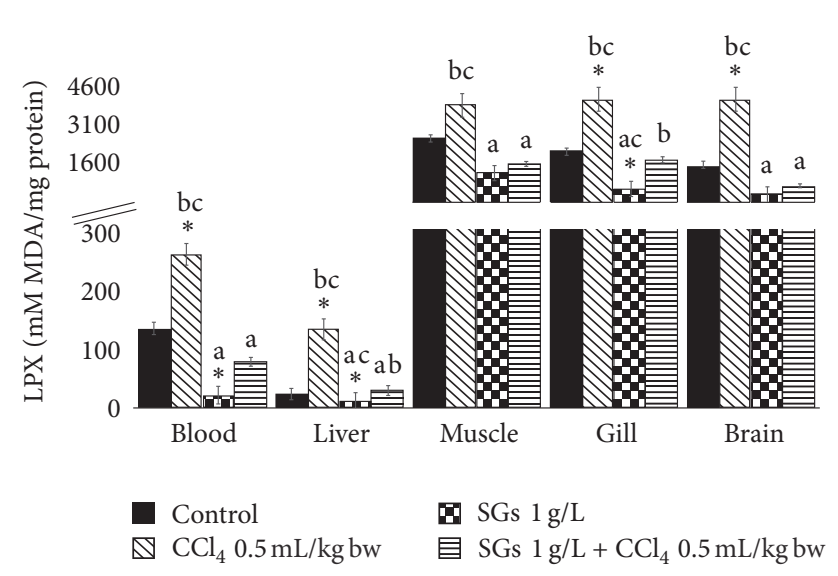

FIGURE 2: LPX in blood, liver, muscle, gill, and brain of C. carpio exposed at $96 \mathrm{~h}$ in different systems. Values are the mean of three replicates \pm SEM. $N=72$ carps. MDA: malondialdehyde. Significantly different $(P<0.05)$ from $*=$ control, $\mathrm{a}=\mathrm{CCl}_{4}, \mathrm{~b}=\mathrm{SGs}$, and $\mathrm{c}=\mathrm{SGs}+\mathrm{CCl}_{4}$. ANOVA and Bonferroni's test.

the control group $(P<0.05)$ were observed in the system with SGs in blood, liver, and gill. The decreases observed were 83.7, 91.1, and $72.3 \%$, respectively. No significant differences were observed in the treatment with SGs $+\mathrm{CCl}_{4}$ in any tissue. Significant decreases with respect to the $\mathrm{CCl}_{4}$ system were found in blood (91.5\%), liver (91.0\%), muscle (68.9\%), gill $(86.1 \%)$ and brain $(90.6 \%)$ in the SGs system. Significant decreases with respect to the $\mathrm{CCl}_{4}$-induced system were found in blood, liver, muscle, gill, and brain in the SGs $+\mathrm{CCl}_{4}$ system. The decreases observed were 69.7, 76.9, 60.0, 58.7, and $83.2 \%$, respectively.

2.3. Protein Carbonyl Content (PCC). PCC results are shown in Figure 3. Significant increases with respect to the control group $(P<0.05)$ were observed in the $\mathrm{CCl}_{4}$ system in blood (514.6\%) and gill (417.9\%). Exposition to SGs (1 g/L) showed significant decreases $(P<0.05)$ with respect to the control

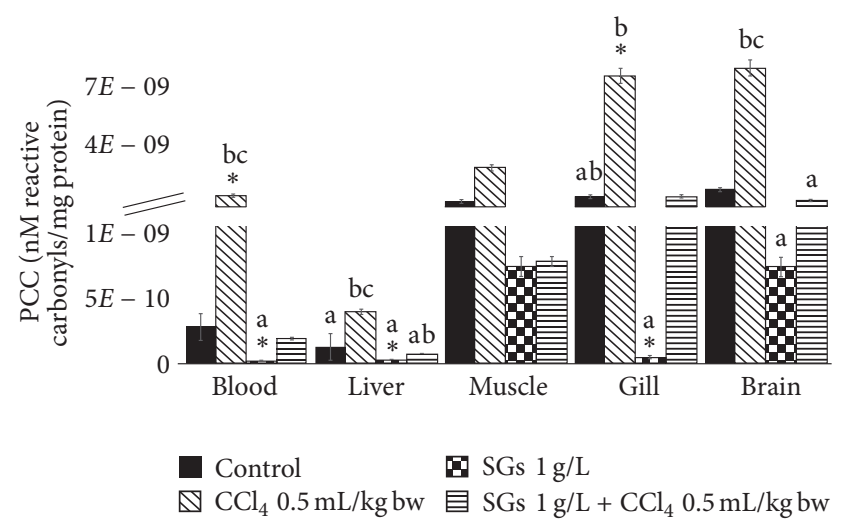

FIgURE 3: PCC in blood, liver, muscle, gill, and brain of C. carpio exposed at $96 \mathrm{~h}$ in different systems. Values are the mean of three replicates \pm SEM. $N=72$ carps. Significantly different $(P<0.05)$ from $*=$ control, $\mathrm{a}=\mathrm{CCl}_{4}, \mathrm{~b}=\mathrm{SGs}$, and $\mathrm{c}=\mathrm{SGs}+\mathrm{CCl}_{4}$. ANOVA and Bonferroni's test.

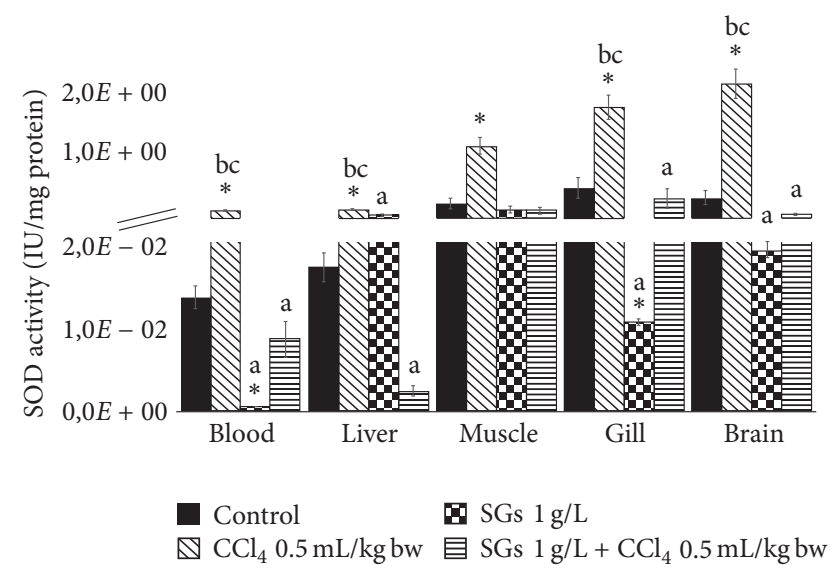

FIGURE 4: SOD activity in blood, liver, muscle, gill, and brain of $C$. carpio exposed at $96 \mathrm{~h}$ in different systems. Values are the mean of three replicates \pm SEM. $N=72$ carps. Significantly different $(P<$ 0.05) from $*=$ control, $\mathrm{a}=\mathrm{CCl}_{4}, \mathrm{~b}=\mathrm{SGs}$, and $\mathrm{c}=\mathrm{SGs}+\mathrm{CCl}_{4}$. ANOVA and Bonferroni's test.

in blood, liver, and gill. These decreases were 91.9, 75.6, and $97.0 \%$, respectively. No significant differences were observed in the treatment with SGs $+\mathrm{CCl}_{4}$ in any tissue. No significant differences of the biomarker were observed in muscle in any treatment. Significant decreases with respect to the $\mathrm{CCl}_{4}$ induced system were observed in the SGs system in blood, liver, gill, and brain. Significant differences were observed in the SGs $+\mathrm{CCl}_{4}$ system with respect to the $\mathrm{CCl}_{4}$ system in blood (88.9\%), liver (80.2\%), gill (80.4\%), and brain (84.0\%). No significant differences were observed in muscle in any treatment.

2.4. Superoxide Dismutase (SOD) Activity. SOD activity is shown in Figure 4. $\mathrm{CCl}_{4}$ treatment showed significant increases in all tissues (blood, liver, muscle, gill, and brain) with respect to control $(P<0.05)$. These increases were 951.9, $672.6,401.2,272.3$, and $562.6 \%$, respectively. SGs exposition 


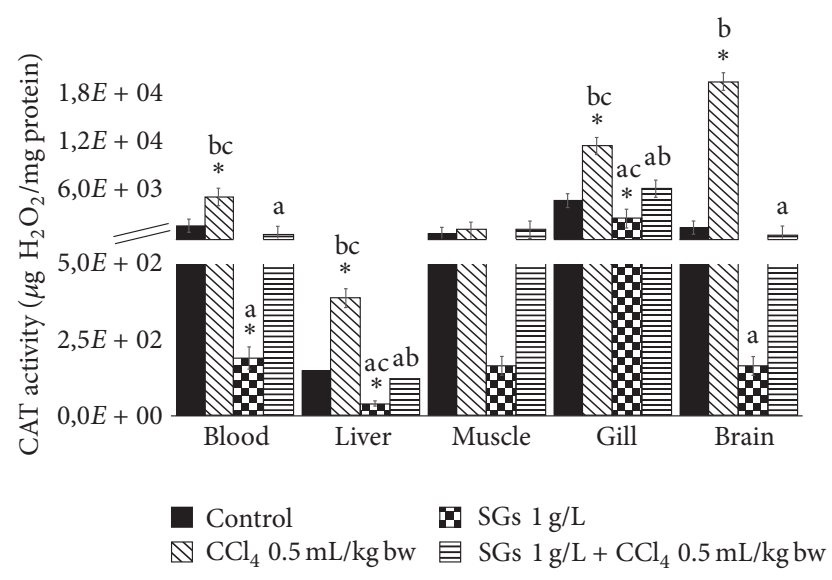

FIGURE 5: CAT enzymatic activity in blood, liver, muscle, gill, and brain of $C$. carpio exposed at $96 \mathrm{~h}$ in different systems. Values are the mean of three replicates \pm SEM. $N=72$ carps. Significantly different $(P<0.05)$ from $*=$ control, $\mathrm{a}=\mathrm{CCl}_{4}, \mathrm{~b}=\mathrm{SGs}$, and $\mathrm{c}=\mathrm{SGs}+\mathrm{CCl}_{4}$. ANOVA and Bonferroni's test.

showed significant decreases $(P<0.05)$ with respect to control in blood (96.1\%) and gills (97.8\%). A significant increase was observed in the liver (166.3\%) with the SGs treatment with respect to the control group. No significant differences were observed in the treatment with SGs $+\mathrm{CCl}_{4}$ in any tissue. Significant decreases with respect to the $\mathrm{CCl}_{4}$ system were observed in blood, liver, and gill in the SGs system. Decreases observed were 99.6, 65.5, and 99.4\%, respectively. Significant decreases in the SGs $+\mathrm{CCl}_{4}$ system were observed in blood (94.0\%), liver (98.2\%), gill (82.3\%), and brain (96.9\%) with respect to the $\mathrm{CCl}_{4}$ system.

2.5. Catalase (CAT) Activity. CAT activity is shown in Figure 5. In the $\mathrm{CCl}_{4}$ system, significant increases were observed with respect to the control group $(P<0.05)$ in blood, liver, gill, and brain $(203.6,161.9,139.8$, and $1233.8 \%$, resp.). Significant decreases with respect to the control group were found in blood (88.3\%), liver (72.6\%), and gill (46.2\%) in the SGs system. No significant differences of the biomarker were observed in muscle in any treatment. No significant differences were observed in the treatment with SGs $+\mathrm{CCl}_{4}$. Significant decreases were found in the SGs system in blood (96.1\%), liver (89.5\%), gill (77.6\%), and brain (99.1\%) with respect to the $\mathrm{CCl}_{4}$ system. Significant decreases were found in the $\mathrm{SGs}+\mathrm{CCl}_{4}$ system in blood, liver, gill, and brain with respect to the $\mathrm{CCl}_{4}$ system. These decreases were 88.0, $67.8,45.4$, and $97.1 \%$, respectively. Significant increases were observed in liver and gill with respect to the SGs system in the SGs $+\mathrm{CCl}_{4}$ system.

\section{Discussion}

Stevia rebaudiana Bertoni, a plant species native to Northeastern Paraguay, is known to accumulate diterpene glycosides. These compounds are nontoxic, high-potency sweeteners that are used as sugar substitutes. The major SGs stevioside and rebaudioside-A constitute $60-70 \%$ and $20-30 \%$, respectively, of the total glycosides in S. Rebaudiana. Several studies have suggested that, besides sweetness, SGs, along with related compounds, may also offer therapeutic benefits, as they have antihyperglycemic, antihypertensive, anti-inflammatory, antitumor, antidiarrheal, diuretic, and immunomodulatory effects [4].

Another important effect of SGs related to the scientific literature is their antioxidant activity. In a study conducted by Shukla et al. [45], they demonstrated that aqueous extracts also inhibited hydroxyl radicals, nitric oxide, and superoxide anions with $\mathrm{IC}_{50}$ values of $100.86,98.73$, and $100.86 \mu \mathrm{g} / \mathrm{mL}$, respectively. The greater amount of phenolic compounds leads to more potent radical scavenging effects as shown by the aqueous leaf extract of $S$. rebaudiana.

OS is one important mechanism of toxicity, given the impact that an imbalance between reactive oxygen species (ROS) and antioxidant defenses has on vital biomolecules such as lipids, proteins, and genetic material, as well as the countless toxicants capable of inducing it (hydrocarbons, metals, pesticides, solvents, and drugs, among other compounds) [46-51]. An increase in the scientific literature suggests that diseases including cardiovascular diseases, diabetes, cancer, neural disorders, arthritis, and aging are caused by or related to the production of ROS which can result in tissue damage and cell death [52-54]. Kim et al. [55] reported that Stevia extracts contain high levels of compounds with ROS scavenging activity.

On the other hand, sugars are well known as ROS scavengers [56] and a number of recent findings point to a prominent role for sugars or sugar-like compounds in oxidative stress defense in plants [55-57]. A study conducted by Hajihashemi and Geuns [58] hypothesized that, due to the high content of sugars present in the SGs, these presented their high antioxidant capacity; however, the results showed that this did not occur.

In the same way as all aerobic organisms, fish such as Cyprinus carpio have an inherent and efficient antioxidant defense system that includes the enzymes SOD, CAT, and GPx and nonenzymatic antioxidant components such as GSH [59]. These enzymes play a preponderant role in defending the cells against free radical-mediated oxidative damage [60] decreased activities, or expressions of these enzymes may predispose tissues to free radical injury [61].

From the above, this study was carried out to investigate the antioxidant properties of SGs in $\mathrm{CCl}_{4}$-induced injuries in a fish model (Cyprinus carpio). The utilization of halogenated alkanes such as $\mathrm{CCl}_{4}, \mathrm{CHCl}_{3}$, or $\mathrm{CHI}_{3}$ has been prohibited due to their severe toxicity; $\mathrm{CCl}_{4}$ however continues to be used as a model substance to elucidate the mechanisms of action of hepatotoxic effects such as fatty degeneration, fibrosis, hepatocellular death, carcinogenicity, and OS. The mechanism through which $\mathrm{CCl}_{4}$ produces its toxic effects is the formation of reactive trichloromethyl radicals $\left({ }^{*} \mathrm{CCl}_{3}\right)$ by CYP450 activity. In the presence of oxygen, ${ }^{\circ} \mathrm{CCl}_{3}$ is quickly transformed into trichloromethyl peroxyl radical $\left(\mathrm{CCl}_{3} \mathrm{O}_{2}{ }^{\circ}\right)$. $\mathrm{CCl}_{3} \mathrm{O}_{2}{ }^{\circ}$ binds covalently to cellular proteins or lipids, which initiates the lipid peroxidation in the cellular membrane [62].

In the current work, treatment of the fish with $\mathrm{CCl}_{4}$ at $96 \mathrm{~h}$ increased significantly the activities of SOD and CAT in 
all tested tissues. In addition, it increased significantly CHP, LPX, and PCC in blood, liver, gill, and brain. These results demonstrate that $\mathrm{CCl}_{4}$ may be a good inducer of OS in common carp Cyprinus carpio.

Antioxidant defenses may be induced by diverse environmental contaminants [63]. SOD is the first mechanism of antioxidant defense and the main enzyme responsible for offsetting the toxic effects induced by the presence of ROS. This is particularly so in the case of the superoxide ion, which is a minor product of mitochondrial respiration [64] and is biotransformed by SOD to hydrogen peroxide, after which CAT and GPx take part in the capture and later dismutation of $\mathrm{H}_{2} \mathrm{O}_{2}$ to $\mathrm{H}_{2} \mathrm{O}$ [31]. As can be seen in Figures 4 and $5, \mathrm{CCl}_{4}$ at a concentration of $0.5 \mathrm{~mL} / \mathrm{kg}$ bw increases significantly the SOD and CAT activity in blood and the four tissues evaluated in this study. Also, there are increases in HPC, LPX, and PCC. Bagnyukova et al. [65] say that LPX products are apparently involved in the upregulation of certain antioxidant enzymes. Therefore, LPX increases in our study might likewise explain the increases in antioxidant enzyme activities that were found. These results would demonstrate that $\mathrm{CCl}_{4}$ is a good inducer of oxidative stress in common carp.

SGs alone system showed an efficient decrease in the oxidative stress biomarkers used in this study with respect to control and $\mathrm{CCl}_{4}$ systems; and to determine the effect of $\mathrm{CCl}_{4}$ exposure on OS system and consequently potential antioxidant effects of SGs on the disturbed system by $\mathrm{CCl}_{4}$, a system was tested using $\mathrm{CCl}_{4} 0.5 \mathrm{~mL} / \mathrm{kg}+\mathrm{SGs} 1 \mathrm{~g} / \mathrm{L}$. The results in this system showed a significant decrease in the cellular oxidation biomarkers (CHP, LPX, and PCC) and the antioxidant enzymes (SOD and CAT) with respect to the $\mathrm{CCl}_{4}$ systems.

These results are in agreement with those of Holvoet et al. [66]; they demonstrate that stevioside treatment of obese diabetic mice improved adipose tissue maturation and increased glucose transport, insulin signaling, and antioxidant defense in white visceral adipose tissues. Together, these increases were associated with a twofold increase of adiponectin. The adiponectin has been associated with improved insulin signaling and antioxidant defense in both the adipose tissue and the aorta of stevioside-treated mice [67].

Also, these authors showed that rebaudioside increased methionine that is directly involved in the regulation of the glutathione antioxidative system. It also increased tryptophan that is involved in the regulation of the defense system through its action as a precursor of antioxidants and its effect on the inflammatory response [68].

In addition to these findings, it was shown that SGs had a very potent ${ }^{\circ} \mathrm{OH}$ scavenging activity $[69,70]$. Several studies have shown that crude extracts of Stevia rebaudiana are responsible for antioxidant activities in murine models, neutralizing radicals such as hydroxyl radicals $\left(\mathrm{OH}^{*}\right)$, superoxide radicals $\left(\mathrm{O}^{2 *}\right)$, and hydrogen peroxide $\left(\mathrm{H}_{2} \mathrm{O}_{2}\right)$.

On the other hand, when SGs were used, a decrease in HPC, LPX, and PCC (Figures 1-3) was observed with respect to the control group and the $\mathrm{CCl}_{4}$ group at concentration of $0.5 \mathrm{~mL} / \mathrm{kg} \mathrm{bw}$. Paradoxically, the levels of antioxidant enzymes SOD and CAT decreased significantly with respect to the control, $\mathrm{CCl}_{4}$ at concentration of $0.5 \mathrm{~mL} / \mathrm{kg} \mathrm{bw}$, and $\mathrm{SGs}+\mathrm{CCl}_{4}$ groups. The decrease in SOD and CAT of the
$\mathrm{CCl}_{4}$ and $\mathrm{SGs}+\mathrm{CCl}_{4}$ groups would demonstrate that the increase of ROS by tetrachloride exposure in common carp is inhibiting the antioxidant enzymes evaluated. Jira et al. [71] suggest that SOD activity may be inhibited if there is an increase in superoxide anion, $\mathrm{H}_{2} \mathrm{O}_{2}$, and peroxynitrite.

In the group in which only SGs were used, a significant decrease with respect to the control was observed, which would demonstrate that the glycosides of steviol are effective in reducing the ROS produced by the basal cellular activity of the carp.

\section{Conclusion}

SGs used alone are not capable of generating oxidative stress and, on the contrary, would appear to induce an antioxidant effect in the common carp Cyprinus carpio. The antioxidant properties of SGs in $\mathrm{CCl}_{4}$-induced injuries in Cyprinus carpio model were proven when comparing the systems with $\mathrm{CCl}_{4}$ alone and the mixture of $\mathrm{CCl}_{4}$ and SGs system. The concentration of SGs which showed an antioxidant activity in the model used was $1 \mathrm{~g} / \mathrm{L}$.

\section{Conflicts of Interest}

The authors declare that there are no conflicts of interest regarding the publication of this paper.

\section{References}

[1] J. Suez, T. Korem, D. Zeevi et al., "Artificial sweeteners induce glucose intolerance by altering the gut microbiota," Nature, vol. 514, no. 7521, pp. 181-186, 2014.

[2] C. Gardner, J. Wylie-Rosett, S. S. Gidding et al., "Non nutritive sweeteners: current use and health perspectives a scientific statement from the American Heart Association and the American Diabetes Association," Diabetes care, vol. 3, no. 8, pp. 17981808, 2012.

[3] F. T. Lange, M. Scheurer, and H. J. Brauch, "Artificial sweeteners-a recently recognized class of emerging environmental contaminants: a review," Analytical and Bioanalytical Chemistry, vol. 403, no. 9, pp. 2503-2518, 2012.

[4] V. Chatsudthipong and C. Muanprasat, "Stevioside and related compounds: therapeutic benefits beyond sweetness," Pharmacology and Therapeutics, vol. 121, no. 1, pp. 41-54, 2009.

[5] Q. Yang, “Gain weight by 'going diet?' artificial sweeteners and the neurobiology of sugar cravings," Yale Journal of Biology and Medicine, vol. 83, no. 2, pp. 101-108, 2010.

[6] J. J. James, P. Thomas, D. Cavan, and D. Kerr, "Preventing childhood obesity by reducing consumption of carbonated drinks: cluster randomised controlled trial," British Medical Journal, vol. 328, no. 7450, p. 1237, 2004.

[7] FDA Food and Drugs Administration, "Cyclamate (Cyclamic Acid, Calcium Cyclamate and Sodium Cyclamate) Commissioner's Decision," http://www.fda.gov/downloads/Food/IngredientsPackagingLabeling/FoodAdditivesIngredients/UCM404344.pdf.

[8] R. Dhingra, L. Sullivan, P. F. Jacques et al., "Soft drink consumption and risk of developing cardiometabolic risk factors and the metabolic syndrome in middle-aged adults in the community," Circulation, vol. 116, no. 5, pp. 480-488, 2007. 
[9] P. L. Lutsey, L. M. Steffen, and J. Stevens, "Dietary intake and the development of the metabolic syndrome: the atherosclerosis risk in communities study," Circulation, vol. 117, no. 6, pp. 754761, 2008.

[10] W. C. Winkelmayer, M. J. Stampfer, W. C. Willett, and G. C. Curhan, "Habitual caffeine intake and the risk of hypertension in women," Journal of the American Medical Association, vol. 294, no. 18, pp. 2330-2335, 2005.

[11] T. I. Halldorsson, M. Strøm, S. B. Petersen, and S. F. Olsen, "Intake of artificially sweetened soft drinks and risk of preterm delivery: a prospective cohort study in 59,334 Danish pregnant women," American Journal of Clinical Nutrition, vol. 92, no. 3, pp. 626-633, 2010.

[12] N. Abo Elnaga, M. I. Massoud, M. Yousef, and H. H. Mohamed, "Effect of stevia sweetener consumption as non-caloric sweetening on body weight gain and biochemical's parameters in overweight female rats," Annals of Agricultural Sciences, vol. 61, no. 1, pp. 155-163, 2016.

[13] N.-C. Kim and A. D. Kinghorn, "Highly sweet compounds of plant origin," Archives of Pharmacal Research, vol. 25, no. 6, pp. 725-746, 2002.

[14] A. Periche, M. L. Castelló, A. Heredia, and I. Escriche, "Influence of drying method on steviol glycosides and antioxidants in Stevia rebaudiana leaves," Food Chemistry, vol. 172, pp. 1-6, 2015.

[15] G. J. Gerwig, E. M. te Poele, L. Dijkhuizen, and J. P. Kamerling, "Chapter one-stevia glycosides: chemical and enzymatic modifications of their carbohydrate moieties to improve the sweet-tasting quality," in Advances in Carbohydrate Chemistry and Biochemistry, vol. 73, pp. 1-72, 2016.

[16] M. C. Carakostas, L. L. Curry, A. C. Boileau, and D. J. Brusick, "Overview: the history, technical function and safety of rebaudioside A, a naturally occurring steviol glycoside, for use in food and beverages," Food and Chemical Toxicology, vol. 46, no. 7, pp. S1-S10, 2008.

[17] S. K. Goyal and R. K. Goyal, "Stevia (Stevia rebaudiana) a biosweetener: a review," International Journal of Food Sciences and Nutrition, vol. 61, no. 1, pp. 1-11, 2010.

[18] "Stevia Market: Global Industry Analysis and Opportunity Assessment 2014-2020," http://www.futuremarketinsights.com/ reports/global-stevia-market.

[19] J. O. Atteh, O. M. Onagbesan, K. Tona, E. Decuypere, J. M. Geuns, and J. Buyse, "Evaluation of supplementary stevia (Stevia rebaudiana, bertoni) leaves and stevioside in broiler diets: effects on feed intake, nutrient metabolism, blood parameters and growth performance," Journal of Animal Physiology and Animal Nutrition, vol. 92, no. 6, pp. 640-649, 2008.

[20] C. Boonkaewwan, C. Toskulkao, and M. Vongsakul, "Antiinflammatory and immunomodulatory activities of stevioside and its metabolite steviol on THP-1 cells," Journal of Agricultural and Food Chemistry, vol. 54, no. 3, pp. 785-789, 2006.

[21] R. Abudula, P. B. Jeppesen, S. E. D. Rolfsen, J. Xiao, and K. Hermansen, "Rebaudioside A potently stimulates insulin secretion from isolated mouse islets: studies on the dose-, glucose-, and calcium-dependency," Metabolism, vol. 53, no. 10, pp. 13781381, 2006.

[22] P. B. Jeppesen, S. Gregersen, C. R. Poulsen, and K. Hermansen, "Stevioside acts directly on pancreatic $\beta$ cells to secrete insulin: actions independent of cyclic adenosine monophosphate and adenosine triphosphate-sensitive $\mathrm{K}+$-channel activity," Metabolism, vol. 49, no. 2, pp. 208-214, 2000.
[23] P. Chan, B. Tomlinson, Y.-J. Chen, J.-C. Liu, M.-H. Hsieh, and J.-T. Cheng, "A double-blind placebo-controlled study of the effectiveness and tolerability of oral stevioside in human hypertension," British Journal of Clinical Pharmacology, vol. 50, no. 3, pp. 215-220, 2000.

[24] M. Puri and D. Sharma, "Antibacterial activity of stevioside towards food-borne pathogenic bacteria," Engineering in Life Sciences, vol. 11, no. 3, pp. 326-329, 2011.

[25] H. Sies, Ed. Elsevier, 2013.

[26] A. Valavanidis, T. Vlahogianni, M. Dassenakis, and M. Scoullos, "Molecular biomarkers of oxidative stress in aquatic organisms in relation to toxic environmental pollutants," Ecotoxicology and Environmental Safety, vol. 64, no. 2, pp. 178-189, 2006.

[27] F. F. Ahmad, D. L. Cowan, and A. Y. Sun, "Detection of free radical formation in various tissues after acute carbon tetrachloride administration in gerbil," Life Sciences, vol. 41, no. 22, pp. 2469-2475, 1987.

[28] Y. Ohta, K. Nishida, E. Sasaki, M. Kongo, and I. Ishiguro, "Attenuation of disrupted hepatic active oxygen metabolism with the recovery of acute liver injury in rats intoxicated with carbon tetrachloride," Research Communications in Molecular Pathology and Pharmacology, vol. 95, no. 2, pp. 191-207, 1997.

[29] F. Ozturk, M. Ucar, I. C. Ozturk, N. Vardi, and K. Batcioglu, "Carbon tetrachloride-induced nephrotoxicity and protective effect of betaine in Sprague-Dawley rats," Urology, vol. 62, no. 2, pp. 353-356, 2003.

[30] N. Tirkey, S. Pilkhwal, A. Kuhad, and K. Chopra, "Hasperidin, a citrus bioflavonoid, decreases the oxidative stress produced by carbon tetrachloride in rat liver and kidney," BMC Pharmacology, vol. 5, no. 1, article 2, pp. 1-8, 2005.

[31] C. Barata, I. Varo, J. C. Navarro, S. Arun, and C. Porte, "Antioxidant enzyme activities and lipid peroxidation in the freshwater cladoceran Daphnia magna exposed to redox cycling compounds," Comparative Biochemistry and Physiology Part C Toxicology \& Pharmacology, vol. 140, no. 2, pp. 175-186, 2005.

[32] W. Dröge, "Free radicals in the physiological control of cell function," Physiological Reviews, vol. 82, no. 1, pp. 47-95, 2002.

[33] H. Malekinejad, A. Alizadeh, H. Cheraghi, S. Meshkin, and F. Dardmeh, "The protective effect of liquorice plant extract on CCl4-induced hepatotoxicity in common carp (Cyprinus carpio)," Veterinary Research Forum, vol. 1, no. 3, pp. 158-164, 2012.

[34] G. Yin, L. Cao, P. Xu, G. Jeney, M. Nakao, and C. Lu, "Hepatoprotective and antioxidant effects of Glycyrrhiza glabra extract against carbon tetrachloride $\left(\mathrm{CCl}_{4}\right)$-induced hepatocyte damage in common carp (Cyprinus carpio)," Fish Physiology and Biochemistry, vol. 37, no. 1, pp. 209-216, 2011.

[35] R. Jia, L. Cao, J. Du, P. Xu, G. Jeney, and G. Yin, “The protective effect of silymarin on the carbon tetrachloride $\left(\mathrm{CCl}_{4}\right)$-induced liver injury in common carp (Cyprinus carpio)," In Vitro Cellular and Developmental Biology-Animal, vol. 49, no. 3, pp. 155-161, 2013.

[36] Z. Y. Jiang, J. V. Hunt, and S. P. Wolff, "Ferrous ion oxidation in the presence of xylenol orange for detection of lipid hydroperoxide in low density lipoprotein," Analytical Biochemistry, vol. 202, no. 2, pp. 384-389, 1992.

[37] J. A. Buege and S. D. Aust, "Microsomal lipid peroxidation," Methods in Enzymology, vol. 52, pp. 302-310, 1978.

[38] R. L. Levine, J. A. Williams, E. R. Stadtman, and E. Shacter, "Carbonyl assays for determination of oxidatively modified proteins," Methods in Enzymology, vol. 233, pp. 346-357, 1994. 
[39] S. Parvez and S. Raisuddin, "Protein carbonyls: novel biomarkers of exposure to oxidative stress-inducing pesticides in freshwater fish Channa punctata (bloch)," Environmental Toxicology and Pharmacology, vol. 20, no. 1, pp. 112-117, 2005.

[40] P. C. Burcham, "Modified protein carbonyl assay detects oxidised membrane proteins: a new tool for assessing drug- and chemically-induced oxidative cell injury," Journal of Pharmacological and Toxicological Methods, vol. 56, no. 1, pp. 18-22, 2007.

[41] K. A. Novoa-Luna, R. Romero-Romero, R. Natividad-Rangel et al., "Oxidative stress induced in hyalella azteca by an effluent from a NSAID-manufacturing plant in Mexico," Ecotoxicology, vol. 25, no. 7, pp. 1288-1304, 2016.

[42] H. P. Misra and I. Fridovich, "The role of superoxide anion in the autoxidation of epinephrine and a simple assay for superoxide dismutase," The Journal of Biological Chemistry, vol. 247, no. 10, pp. 3170-3175, 1972.

[43] R. Radi, J. F. Turrens, L. Y. Chang, K. M. Bush, J. D. Crapo, and B. A. Freeman, "Detection of catalase in rat heart mitochondria," The Journal of Biological Chemistry, vol. 266, no. 32, pp. 2202822034, 1991.

[44] M. M. Bradford, "A rapid and sensitive method for the quantitation of microgram quantities of protein utilizing the principle of protein dye binding," Analytical Biochemistry, vol. 72, no. 1-2, pp. 248-254, 1976.

[45] S. Shukla, A. Mehta, P. Mehta, and V. K. Bajpai, "Antioxidant ability and total phenolic content of aqueous leaf extract of stevia rebaudiana bert," Experimental and Toxicologic Pathology, vol. 64, pp. 807-811, 2012.

[46] A. F. Hernández, M. Lacasaña, F. Gil, M. Rodríguez-Barranco, A. Pla, and O. López-Guarnido, "Evaluation of pesticideinduced oxidative stress from a gene-environment interaction perspective," Toxicology, vol. 307, pp. 95-102, 2013.

[47] A. Sureda, S. Tejada, A. Boxsa, and S. Deudero, "Polycyclic aromatic hydrocarbon levels and measures of oxidative stress in the mediterranean endemic bivalve Pinna nobilis exposed to the Don Pedro oil spill," Marine Pollution Bulletin, vol. 71, no. 1-2, pp. 69-73, 2013.

[48] S. Espín, E. Martínez-López, M. León-Ortega, J. E. Martínez, and A. J. García-Fernández, "Oxidative stress biomarkers in eurasian eagle owls (Bubo bubo) in three different scenarios of heavy metal exposure," Environmental Research, vol. 131, pp.131134, 2014.

[49] L. M. Gómez-Oliván, M. Galar-Martínez, H. Islas-Flores, S. García-Medina, and N. Sanjuan-Reyes, "DNA damage and oxidative stress induced by acetylsalicylic acid in Daphnia magna," Comparative Biochemistry and Physiology Part-C: Toxicology and Pharmacology, vol. 164, pp. 21-26, 2014.

[50] M. Galar-Martínez, L. M. Gómez-Oliván, A. Amaya-Chávez, C. Razo-Estrada, and S. García-Medina, "Oxidative stress induced on cyprinus carpio by contaminants present in the water and sediment of madín reservoir," Journal of Environmental Science and Health-Part A Toxic/Hazardous Substances and Environmental Engineering, vol. 45, no. 2, pp. 155-160, 2010.

[51] N. Sanjuan-Reyes, L. M. Gómez-Oliván, M. Galar-Martínez et al., "Effluent from an NSAID-manufacturing plant in Mexico induces oxidative stress on Cyprinus carpio," Water, Air, and Soil Pollution, vol. 224, no. 9, 2013.

[52] D. Zhu, Z. Shen, J. Liu et al., "The ROS-mediated activation of STAT-3/VEGF signaling is involved in the 27-hydroxycholesterol-induced angiogenesis in human breast cancer cells," Toxicology Letters, vol. 264, pp. 79-86, 2016.
[53] R. V. Roy, P. Pratheeshkumar, Y.-O. Son et al., "Different roles of ROS and Nrf2 in $\mathrm{Cr}(\mathrm{VI})$-induced inflammatory responses in normal and $\mathrm{Cr}(\mathrm{VI})$-transformed cells," Toxicology and Applied Pharmacology, vol. 307, pp. 81-90, 2016.

[54] E. Belaidi, J. Morand, E. Gras, J. L. Pépin, and D. Godin-Ribuot, "Targeting the ROS-HIF-1-endothelin axis as a therapeutic approach for the treatment of obstructive sleep apnea-related cardiovascular complications," Pharmacology Therapeutics, vol. 168, pp. 1-11, 2016.

[55] I. S. Kim, M. Yang, O. H. Lee, and S.-N. Kang, "The antioxidant activity and the bioactive compound content of Stevia rebaudiana water extracts," LWT-Food Science and Technology, vol. 44, no. 5, pp. 1328-1332, 2011.

[56] R. Morelli, S. Russo-Volpe, N. Bruno, and R. L. Scalzo, "Fentondependent damage to carbohydrates: free radical scavenging activity of some simple sugars," Journal of Agricultural and Food Chemistry, vol. 51, no. 25, pp. 7418-7425, 2003.

[57] A. Nishizawa, Y. Yabuta, and S. Shigeoka, "Galactinol and raffinose constitute a novel function to protect plants from oxidative damage," Plant Physiology, vol. 147, no. 3, pp. 1251-1263, 2008.

[58] S. Hajihashemi and J. M. C. Geuns, "Radical scavenging activity of steviol glycosides, steviol glucuronide, hydroxytyrosol, metformin, aspirin and leaf extract of Stevia rebaudiana," Free Radicals and Antioxidants, vol. 3, pp. 34-41, 2013.

[59] R. M. Martínez-Alvarez, A. E. Morales, and A. Sanz, "Antioxidant defenses in fish: biotic and abiotic factors," Reviews in Fish Biology and Fisheries, vol. 15, no. 1-2, pp. 75-88, 2005.

[60] S. Ozden, B. Catalgol, S. Gezginci-Oktayoglu, P. Arda-Pirincci, S. Bolkent, and B. Alpertunga, "Methiocarb-induced oxidative damage following subacute exposure and the protective effects of vitamin E and taurine in rats," Food and Chemical Toxicology, vol. 47, no. 7, pp. 1676-1684, 2009.

[61] H.-H. Wang, T.-M. Hung, J. Wei, and A.-N. Chiang, "Fish oil increases antioxidant enzyme activities in macrophages and reduces atherosclerotic lesions in apoE-knockout mice," Cardiovascular Research, vol. 61, no. 1, pp. 169-176, 2004.

[62] S. A. Levine and J. H. Reinhardt, "Biochemical-pathology initiated by free radicals, oxidant chemicals, and therapeutic drugs in the etiology of chemical hypersensitivity disease," Journal of Orthomolecular Psychiatry, vol. 12, no. 3, pp. 166-183, 1983.

[63] T. Vlahogianni, M. Dassenakis, M. J. Scoullos, and A. Valavanidis, "Integrated use of biomarkers (superoxide dismutase, catalase and lipid peroxidation) in mussels Mytilus galloprovincialis for assessing heavy metals' pollution in coastal areas from the saronikos gulf of greece," Marine Pollution Bulletin, vol. 54, no. 9, pp. 1361-1371, 2007.

[64] R. van der Oost, J. Beyer, and N. P. E. Vermeulen, "Fish bioaccumulation and biomarkers in environmental risk assessment: a review," Environmental Toxicology and Pharmacology, vol. 13, no. 2, pp. 57-149, 2003.

[65] T. V. Bagnyukova, O. I. Chahrak, and V. I. Lushchak, "Coordinated response of goldfish antioxidant defenses to environmental stress," Aquatic Toxicology, vol. 78, no. 4, pp. 325-331, 2006.

[66] P. Holvoet, A. Rull, A. García-Heredia et al., "Stevia-derived compounds attenuate the toxic effects of ectopic lipid accumulation in the liver of obese mice: a transcriptomic and metabolomic study," Food and Chemical Toxicology, vol. 77, pp. 22-33, 2015.

[67] T. Fiaschi, F. Magherini, T. Gamberi, P. A. Modesti, and A. Modesti, "Adiponectin as a tissue regenerating hormone: more than a metabolic function," Cellular and Molecular Life Sciences, vol. 71, no. 10, pp. 1917-1925, 2014. 
[68] J. M. C. Geuns and T. Struyf, "Radical scavenging activity of steviol glycosides and steviol glucuronide," in Proceedings of the 4th EUSTAS Stevia Symposium, Stevia, Science no Fiction, J. M. C. Geuns, Ed., pp. 191-207, KU Leuven, Leuven, Belgium, 2010.

[69] B. Geeraert, F. Crombé, M. Hulsmans, N. Benhabilès, J. M. Geuns, and P. Holvoet, "Stevioside inhibits atherosclerosis by improving insulin signaling and antioxidant defense in obese insulin-resistant mice," International Journal of Obesity, vol. 34, no. 3, pp. 569-577, 2010.

[70] S. Stoyanova, J. Geuns, É. Hideg, and W. Van den Ende, "The food additives inulin and stevioside counteract oxidative stress," International Journal of Food Sciences and Nutrition, vol. 62, no. 3, pp. 207-214, 2011.

[71] W. Jira, G. Spiteller, and A. Richter, "Increased levels of lipid oxidation products in low density lipoproteins of patients suffering from rheumatoid arthritis," Chemistry and Physics of Lipids, vol. 87, no. 1, pp. 81-89, 1997. 

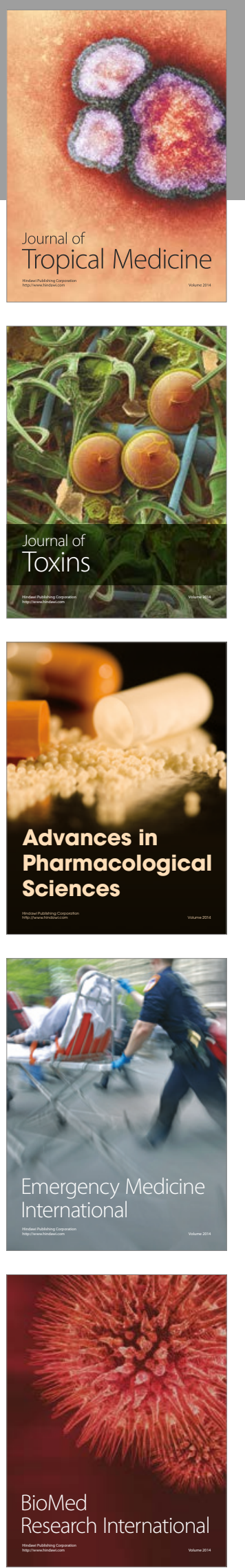
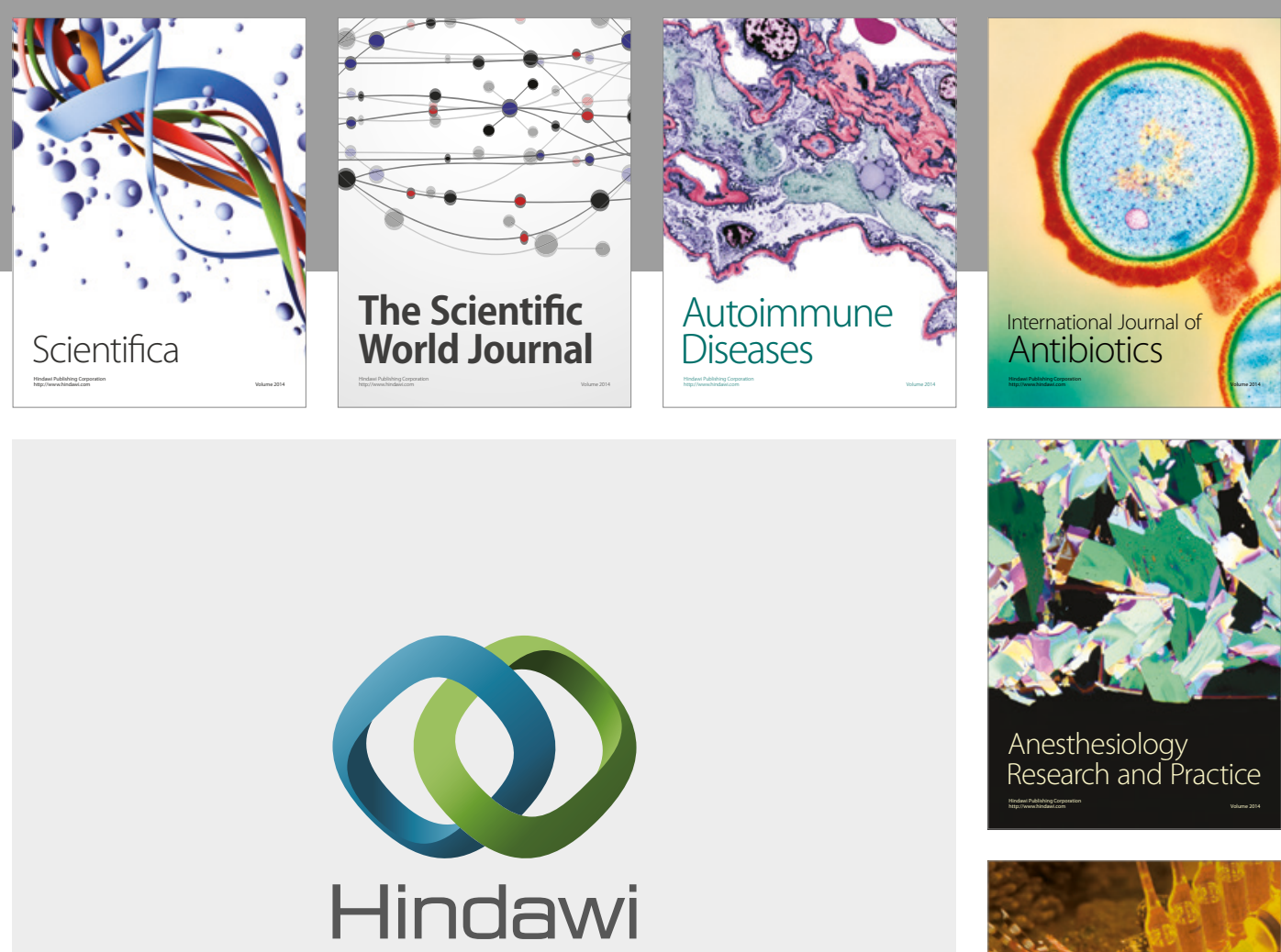

Submit your manuscripts at

https://www.hindawi.com
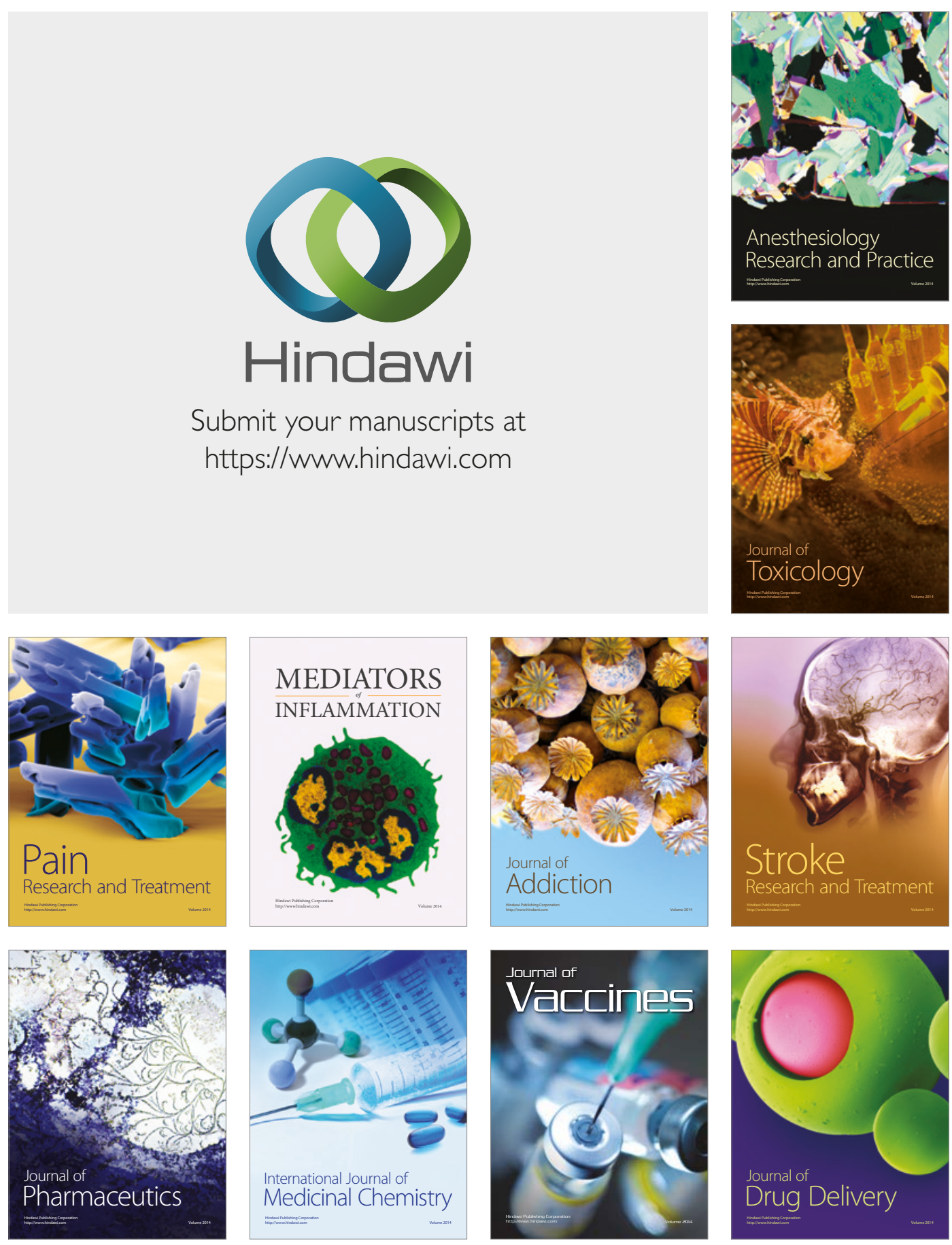